\title{
Review Article \\ Genetic markers to gastrointestinal nematode resistance in sheep: a review
}

\author{
A. KRAWCZYK, E. SŁOTA
}

National Research Institute of Animal Production, Department of Immuno- and Cytogenetics, Ul. Krakowska 1,
32-083 Balice, Poland, E-mail: akrawczyk@izoo.krakow.pl, eslota@izoo.krakow.pl

\section{Summary}

Nematode parasites are the major animal health constraint in sheep production on pasture and cause serious economic losses. Because of failure of anthelmintic drenches, a major research effort has been underway to examine alternatives to chemical control. One of them is selecting sheep which are genetically resistant to parasitic nematodes. However, this last is not widely practiced because of the difficulty of measuring parasite resistance which mostly relies on indirect criteria such as number of nematode eggs passed in the sheep faeces (FEC) packed cell volume (PCV) or enhanced number of eosinophils in peripheral blood. Despite the well known host immune reaction it has been impossible to standardize any immunological parameter and use it as an indicator of parasitic infection. The aim of finding some genetic markers associated with resistance/susceptibility to nematodes is to make diagnostic work easier and conduct an earlier selection of desirable genotypes. However, searching for reliable genetic markers is rather difficult due to different sheep's manifestation of resistance to either the adult or larval stages of the same parasite species and against the same parasitic stage and various manifestations of the immune responses and antigens against parasites. This review summarizes findings reported in the literature relating to genetic markers to gastrointestinal nematodes resistance in sheep.

Key words: gastrointestinal nematode; parasites; sheep; resistance/susceptibility

\section{Introduction}

Nematode resistance of animals can be defined as an enhanced natural ability to both prevent establishment of larval nematodes and evict any that do establish (Douch et al., 1996).

Nematode resistance is a trait of primary interest for live- stock industries because of its economical impact on sheep breeding, such as cost of anthelminthic treatment, increased labour for sheep and pasture management. To these losses have been added indirect costs like decreased production in live weight (McEwan et al., 1992; Bouix et al., 1998), wool, fertility and survival (Dominik, 2005).

Since it has been revealed that nematode resistance has moderate heritability estimated about 0.3 (Bisset et al., 1992; Eady et al., 1996; Boux et al., 1998; Baker et al., 1999 ) there have been undertaken many approaches to find the genetic basis underlying the resistance or susceptibility phenotype.

In order to get a desirable resistant flock a vast selection work must be made using such parameters as number of parasite eggs in sheep faeces (FEC), packed cell volume (PCV) which measures hemophilia caused mainly by infections with blood suckling internal parasites, such as $H$. contortus, and less commonly eosinophilia. All three parameters have shown heritability which ranged between 0.12 and 0.44 for FEC (Watson et al., 1986; Baker et al., 1991; Morris et al., 1997; Charon et al., 2000) 0.15 and 0.36 for PCV (Alberts et al., 1987; Vanisetti et al., 2004) and for eosinophilia at the level of 0.31 (Stear et al., 2002). Furthermore, these three parameters indicate repeatability within the seasons and years (Doligalska et al., 1997; Moskwa et al., 1998; Moskwa et al., 2000; Vanimisetti et al., 2004) on the average 0.48 for FEC (Barger \& Dash, 1987; Doligalska et al., 1997) 0.44 for PCV (Bekele et al., 1991) and 0.38 for eosinophil counts (Moskwa et al., 1998; Doligalska et al., 1999). In addition, FEC values have been negative correlated with either PCV or eosinophils count (Moskwa et al., 1998; Amarante et al., 1999; Stear et al., 2002; Amarante et al., 2003; Vanimisetti et al., 2004).

Although both FEC and PCV values are commonly used as indicators of gastrointestinal parasite infections they have a few limitations, such as inability to store samples for a long time and no possibility to undertake the laborious 
examinations automatically and accurately (Douch et al., 1996; Stear et al., 1999).

In general, resistance to nematode infection is critically dependent on the type of CD $+\mathrm{T}$ cells which can be divided into two helper T cells subsets, Th1 and Th2.

It is suggested that more intensive Th1 type cell response with the absence of Th2 type cell causes host susceptibility to a pathogen (Else \& Finkelman, 1998; Gause et al., 2003). Therefore the immune response against gastrointestinal nematodes infection in resistant sheep lines is expressed by enhanced Th2 type cells. These are claimed to be a characteristic feature of nematode parasites infection (Maizels et al., 1993). Th2 type cells secrete specific cytokines which on appearance activate production of parasite-specific immunoglobulin A (IgA), IgG1 and IgE (Else \& Finkelman, 1998; Stear et al., 1999; Strain \& Stear, 2001; Pernthaner et al., 2005; Henderson \& Stear, 2006) eosinophils and mast cells (Else \& Finkelman, 1998; Amarante et al., 2005).

The knowledge of host immune response to nematode infection is crucial for undertaking genetic approaches. However, although the increased number of mast cells and eosinophils in the gastrointestinal mucosa, elevated levels of nematode-specific antibodies in serum and the presence of molecules having anti-parasitic activity in gastrointestinal mucus are highly specific symptoms of nematode inflammation, they are not stable (Meeusen et al., 2005) and depend on the parasite naivety status of the sheep (Pernthaner et al., 2005). These factors prevent researchers from using them as indicators of gastrointestinal nematodes infection and explain why an accurate DNA test that would make a diagnostic work easier and conduct earlier selection of desirable genotypes has not yet been worked out.

\section{Genetic markers}

The genetic basis to nematode resistance has been established by findings that some sheep breeds are more resistant to nematodes than others. The studies undertaken in Poland revealed that Polish Long-Wool sheep were more resistant to gastro intestinal nematodes than Weisse Sheep, Blackheaded, Berrichonne du Cher and Suffolk breeds (Nowosad et al., 2005a, b). Moreover, it has been noticed that most of the examined Polish primitive Heath Sheep breed (Wrzosówka Sheep) had relatively low or zero faecal egg counts and enhanced ability to increased eosinophil production against parasites which led to the suggestion that this breed could be naturally resistant to gastrointestinal parasites (Moskwa et al., 1998, 1999a, $1999 b$ ). In addition, in number of independent studies two other breeds have been identified as resistant to the parasites, these are St Croix sheep (Gamble \& Zajac, 1992) and Red Massai Sheep (Mugambi et al., 2005).

Genetic markers within the ovine major histocompatibility complex (Ovar-MHC) locus

The genetic approaches have been previously focused on genes of the ovine major histocompatibility complex
(Ovar-MHC) which consists of class I, II and III regions and is sited on sheep chromosome 20 between bands q15 and q23 (Hediger et al., 1991).

Among all three groups the most polymorphic and by now the best characterized are class II genes (Dukkipati et al., 2006). Within the II class genes DQ and DR subregions have been studied in detail. Each of them code for both chain $\alpha$ (gene A) and chain $\beta$ (gene B) and exhibit high levels of polymorphism (Amills et al., 1998). Locus DRB codes the protein which is within binding area to antigens on macrophages and lymphocytes B (Escayg et al., 1996; Anderson \& Rask, 1998). High polymorphism of this locus has been shown by restriction fragments length polymorphism (RFLP) and short tandem repeats (STRs, microsatellite) polymorphism (Schwaiger et al., 1996; Charon et al., 2002; Gruszczyńska et al., 2005; Stear et al., 2005). Moreover, using microsatellite polymorphism within DRB1 locus it has been displayed that polymorphism of this region is connected with sheep resistance or susceptibility to infections by gastrointestinal nematodes (Schwaiger et al., 1996; Stear et al., 1996; Charon et al., 2002; Stear et al., 2005).

Considering the potential role of the Ovar-DRA and DQA genes in sheep the response to gastrointestinal nematodes infection in Ovar-DQA genes showed high levels of polymorphism while only limited polymorphism was seen in Ovar-DRA genes (Fabb et al., 1993). In susceptible sheep line has been noticed more intensive expression of OvarDQA1 null alleles (lack of DQA1 alleles) that probably caused a failure in presenting parasite antigens to $\mathrm{CD}+\mathrm{T}$ cells. However this association was found in only one of three sheep breeds investigated by Kean et al. (2007). This suggests that a lack of DQA1 alleles could be responsible for the susceptible phenotype only as combined with other MHC alleles linked to Ovar-DQA1, a non-MHC allele in linkage disequilibrium with DQA1 and the level of expression of DQA1 on antigen presenting cells.

At last, a microsatellite polymorphism at the Ovar-DY locus was found to be significantly associated with resistance to $T$. circumcincta in Scottish Blackface sheep (Buitkamp et al., 1996).

Although the MHC-class I genes are present on the majority of cell types until now they have been poorly characterised. They code class I molecules which present antigenic peptides to CD8+ T cells (Kaufman et al., 1994; Dukkipati et al., 2006). Within Ovar-MHC class I locus have been found a few RFLP and polymorphic microsatellite sequences which differ among sheep breeds (Buitkamp et al., 1996; Charon et al., 2001; Gruszczyńska et al., 2002). Sheep with gastrointestinal nematodes-resistant alleles at this locus have displayed significant reduction in FEC of $T$. circumcincta in Scottish Blackface sheep (Buitkamp et al., 1996) and in FEC of other gastrointestinal nematode species in Polish Heath sheep (Charon et al., 2000).

Within Class III genes an allele of $\mathrm{C} 4$ gene is supposed to be involved in determining the resistance/susceptibility to gastro intestinal parasites (Wetherall et al., 1991). 
Quantitative trait loci (QTL)

In order to find QTLs for resistance to nematodes and to place them on exact chromosomes all 26 sheep autosomes have been scanned. This resulted in finding of QTLs on some chromosomes and a few microsatellites markers closely associated to genes supposed to play a role in parasite resistance. Unfortunately, approaches undertaken to find single QTLs that would be significantly associated with the nematode-resistance have failed which suggests that most of genes controlling this trait are of relatively small effect (Crawford et al., 2006).

To begin with, chromosome 1 has been revealed as containing genes influencing the number of adult larvae of $T$. colubriformis in the abomasum and its FEC level (Beh et al., 2002). Davis et al. (2006) found evidence for QTL on chromosome 2 associated with Nematodirus FEC. On chromosome 3, where the interferon gamma locus is, a few important markers have been found associated with IgA expression, Strongyle FEC (Coltman et al., 2001; Beh et al., 2002; Davis et al., 2006) and response to T. circumcincta (Crawford et al., 2006). QTL found on chromosomes 3 and 14 are connected with Nematodirus FEC (Coltman et al., 2001; Davis et al., 2006). Chromosome 5, containing genes encoding cytokines Il-3, IL-4, IL-5 has been scanned (Benavides et al., 2002) in order to find markers useful in selection of animals. As a result there has been found one reliable microsatellite marker. QTL on chromosome 6 showed a significant association with FEC after primary and secondary challenge with $T$. colubriformis (Beh et al., 2002). As the MHC is located on chromosome 20 it was obvious that this chromosome would be under careful investigation. The DRB1 locus within the ovine MHC has been revealed as associated with resistance to T. circumcincta (Schwaiger et al., 1995; Stear et al., 1996) and other gastrointestinal species (Charon et al., 2002) and one microsatellite marker for the DY locus has been confirmed (Buitkamp et al., 1996). Furthermore, telomeric ends of chromosome 8 also were identified as having a significant QTL for parasite resistance. In addition, there was an identified QTL on chromosome 23 associated with immune function traits of $\operatorname{IgE}$ antibodies and $T$. colubriformis specific IgG antibodies (Crawford et al., 2006).

\section{Microarrays}

Microarray technology has become a tool to measure and analyse the expression of thousands of genes. Microarrays have identified from 100 (Diez-Tascon et al., 2005) to 300 (Keane et al., 2007) differential gene expression patterns between sheep genetically resistant and those that are susceptible to parasitic nematodes. In resistant animals more highly expressed were genes associated with cell morphology, cellular development, and the immune and lymphatic system development and function. While in susceptible animals higher expression is displayed by stress response genes and those which are involved in gene regulation and DNA binding (Keane et al., 2007). In Diez-Tascon et al. (2005) two genes highly expressed in resistant animals coded for two smooth muscle proteins: transgelin (TAGLIN) and actin- $\gamma 2$ (ACTG2). To these genes Keane et al. (2007) have added other genes expressed in the intestinal smooth muscle, these are Wiskott-Aldrich syndrome family gene 2 (WASF2), myosin light chain kinase (MYLK) and desmin (DES).

The explanation of contradictory effect of association of MHC gene polymorphism with FEC reduction has been found using microarray approaches. Dies-Tascon et al. (2005) have suggested that expression of MHC class II genes in the resistant lambs may only be effective in reducing parasite infection if combined with a set of certain MHC alleles, Keane et al. (2007) indicated that the crucial role in this process lay in the presence or lack DQA1 alleles. This explained why in some reports an association between MHC alleles and FEC reductions has been pointed out (Schwaiger et al., 1995; Buitkamp et al., 1996), while this relationship in another studies has been not observed (Cooper et al., 1989; Crawford et al., 1997).

\section{Conclusion}

In spite of the development of our knowledge about parasitic processes the subject is still a challenge. Since the genes modulated during parasite infection have been divided into three functional classes: (1) genes improving the host survival, (2) host genes activated by factors released by parasites to promote parasite's growth and (3) genes incidentally regulated by activation of the first two classes the biggest challenge for scientists is to determine the class of genes to which the investigated gene belongs (Blader et. al., 2001). Microarray experiments could help solve these problems. It presents a huge possibility to examine expressions of many genes during exact processes at the same time, identify the parasitic factors that modulate host cell transcription and determine the host transcriptional and signaling pathways influenced by infection. However, it has also few limitations such as hybridization between some highly conserved genes presented in the parasite and host genomes or some more common cases when some pathogens fail to activate their typical response genes (Boothroyd et al., 2003). In addition, many laboratories cannot afford to introduce microarray technology because of its high costs. It is also worth noting that development of science could not be achieved without integration of various analyzing methods coming from different laboratories using arrays, proteomics, metabolics, genetics and others. Only a complex insight into inflammatory processes caused by parasites can lead to find a method to overcome such diseases.

\section{References}

Albers, G. A. A., Gray, G. D., Piper, L. R., Barker, J. S. F., LE JAMBRE, L. F., BARGER, I. A. (1987): The genetics of resistance and resilience to Haemonchus contortus infection in young Merino sheep. Int. J. Parasitol., 17: $1355-$ 1363 
Amarante, A. F. T., Bricarello, P. A., Huntley, J. F., Mazzolin, L. P., Gomes, J. C. (2005): Relationship of abomasal histology and parasite-specific immunoglobulin A with the resistance to Haemonchus contortus infection in three breeds of sheep. Vet. Parasitol., 128: 99 - 107

Amarante, A. F. T., Bricarello, P. A., Rocha, R. A., GENNARI, S. M. (2003): Resistance of Santa Ines, Suffolk and Ile de France sheep to naturally acquired gastrointestinal nematode infections. Vet. Parasitol., 120: 91 - 106 Amarante, A. F. T., Craig, T. M., RAmSey, W. S., Davis, S. K., BAZER, F. W. (1999): Nematode burdens and cellular responses in the abomasal mucosa and blood of Florida Native, Rambouillet and crossbreed lambs. Vet. Parasitol., 80: $311-324$

Amills, M., RamiYa, V., Norimine, J., Lewin, H. A. (1998): The major histocompatibility complex of ruminants. Rev. Sci. Tech., 17: $108-120$

ANDERSON, L., RASK, L. (1998): Characterisation of the MHC class II region in cattle: The number of DQ genes varies between genotypes. Immunogenetics, 27: 110 - 120 BAKer, R. L., WAtson, T. G., Bisset, S. A., Vlassoff, A., Douch, P. G. C. (1991): Breeding sheep in New Zealand for resistance to internal parasites: research results and commercial applications. In: GRAY G. D. \& WOOLASTON R. R. (Eds) Breeding for disease resistance in Sheep. Australian Wool Corporation, Melbourne, 19 - 32

Baker, R. L., Mwamachi, D. M., Audho, J. O., Aduda, E. O., THORPE, W. (1999): Genetic resistance to gastrointestinal nematode parasites in Red Maasai, Dorper and Red Massai x Dorper ewes in the sub-humid tropics. Anim. Sci., 69: 335 - 344

BARGER, I. A., DASH, K. M. (1987): Repeatability of ovine fecal egg counts and blood packed cell volumes in Haemonchus contortus infections. Int. J. Parasitol., 17: 977 980

Beh, K. J., Hulme, D. J., Callaghan, M. J., Leish, Z., Lenane, I., Windon, R. G., Maddox J. F. (2002): A genome scan for guantitative trait loci affecting resistance to Trichostrongylus colubriformis in sheep. Anim. Genet., 33: $97-106$

BeKele, T., Kasali, O. B., Rege, J. (1991): Repeatability of measurements of packed cell volume and egg count as indicators of endoparasite load and their relationship with sheep productivity. Acta Trop., 50: $151-160$

Benavides, M. V., Weimer, T. A., Borba, M. F. S., BERNE, M. E. A., SACCO, A. M. S. (2002): Association between microsatellite markers of sheep chromosome 5 and faecal egg counts. Small Rumin. Res., 46: 97 - 105

Bisset, S. A., Vlassoff, A., Morris, C. A., Southey, B. R., BAKer, R. L., PARKer, A. G. H. (1992): Heritability and genetic correlations among faecal egg counts and productivity traits in Romney sheep. N. Z. J. Agric. Res., 35: $51-58$

Blader, I. J., Manger, I. D., Boothroyd, J. C. (2001): Microarray analysis previously unknown changes in Toxoplasma gongii-infected human cells. J. Biol. Chem., 26: $24223-24231$

Boothroyd, J. C., Blader, I., Cleary, M., Singh, U.
(2003): DNA microarrays in parasitology: strengths and limitations. Trends Parasitol., 19: 470 - 476

BouiX, J., KrupińsKi, J., RZEPeCKI, R., Nowosad, B., SKRZYZALA, I., ROBORZYNSKI, M., FUDALEWICZNiemczyK, W., Skalska, M., Malczewski, A., GRUNeR, L. (1998): Genetic resistance to gastrointestinal nematode parasites In Polish long-wool sheep. Int. J. Parasitol., 28: $1797-1804$

Buitkamp, J., Filmether, P., Stear, M. J., Epplen, J. T. (1996): Class I and class II Major histocompatibility complex alleles are associated with faecal egg counts following natural, predominantly Ostertargia circumcincta infection. Parasitol. Res., 82: 693 - 696

Charon, K. M., Moskwa, B., GruszczyńsKa, J., KuryŁ, J., PierzchałA, M., RutKowski, R. (2001): Realationship between polymorphism in locus OMHC1 (MHC class I) and resistance to nematodes in Polish Heatherhead Sheep. Anim. Sci. Pap. Rep., 19: 285 - 292

Charon, K. M., Moskwa, B., Nowak, Z., SzydŁowski, M. (2000): Genetic parameters for faecal egg count following natural nematode infections and correlation with productive traits in Polish Heath Sheep. J. Anim. Feed Sci., 9: $461-470$

Charon, K. M., Moskwa, B., Rutkowski, R., GruszCZyŃSKA, J., ŚWIDEREK, W. (2002): Microsatellite polymorphism in DRB1 gene (MHC class II) and its relation to nematode faecal egg count in Polish Heath Sheep. J. Anim. Feed Sci., 11: $47-58$

Coltman, D. W., Wilson, K., Pilkington, J. G., Stear, M. J., Pemberton, J. M. (2001): A microsatellite polymorphism in the gamma interferon gene is associated with resistance to gastrointestinal nematodes in a naturallyparasitized population of Soay sheep. Parasitology, 122: $571-582$

COOPER, D. W., VAn OORSChOt, R. A. H., PIPER, L. R., LE JAMBRE, L. F. (1989): No association between the ovine leukocyte antigen (OLA) system in the Australian Merino and susceptibility to Haemonchus contortus infestation. Int. J. Parasitol., 15: $101-109$

Crawford, A. M., McEwan, J. C., Dodds, K. G., Wright, C. S., Bisset, S. A., Macdonald, P. A., Knowler, K. J., Greer, G. J., Green, R. S., Shaw, R. J., Paterson, K. A., Cuthbertson, R. P., Vlassoff, A., SQuire, D. R., West, C. J., PhuA, S. H. (1997): Proceedings of the 12th Conference on Resistance to Nematode Parasites in Sheep. Part 1. Dubbo, NSW, Australia, $58-62$

Crawford, A. M., Paterson, K. A., Dodds, K. G., DiezTascon, C., Williamson, P. A., Roberts Thomson, M., Bisset, S. A., Beattie, A. E., Greer, G. J., Green, R. S., WheEler, R., Shaw, R. J., KnOwler, K., McEwan, J. C. (2006): Discovery of quantitative trait loci for resistance to parasitic nematode infection in sheep: I. Analysis of outcross pedigrees. BMC Genomics, 7: 178

Davis, G., Stear, M. J., Benothman, M., Abuagob, O., KerR, A., Mitchell, S., Bishop, S. C. (2006): Quantitative trait loci associated with parasitic infection in Scottish Blackface sheep. Heredity, 96: 252 - 258 
Diez-Tascon, Ch., Keane, O. M., Wilson, T., Zadissa, A., Hyndman, D. L., BAIRD, D. B., MCEWAN, J., CRAWFORD, A. M. (2005): Microarray analysis of selection lines from outbred populations to identify genes involved with nematode parasite resistance in sheep. Physiol. Gen., 21: $59-69$

Doligalska, M., Moskwa, B., Niznikowski, R. (1997): The repeatability of faecal egg counts in Polish Wrzosówka sheep. Vet. Parasitol., 70: 241 - 246

Doligalska, M., Moskwa, B., Stear, M. J. (1999): Relationship among peripheral eosinophil peroxidase activity, interleukin-5 concentration and faecal nematode egg count during natural, mixed gastrointestinal nematode infection. Vet. Immunol. Immunopathol., 70: 299 - 308

DOMINIK, S. (2005): Qantitive trait loci for internal nematode resistance in sheep: a review. Genet. Sel. Evol., 37: $83-96$

Douch, P. G. C., Green, R. S., Morris, C. A., McEewan, L. C., Windon, R. G. (1996): Phenotypic markers for selection of nematode-resistance sheep. Int. J. Parasitol., 26, $899-911$

Dukkipati, V. S. R., Blair, H. T., Garrick, D. J., MurRAY, A. (2006): Ovar-MHC - ovine major histocopatibility complex: structure and gene polymorfisms. Genet. Mol. Res., 5: 581 - 608

EADY, S. J., WoOlaston, R. R., MORTIMER, S. I., LEWER, R. P., RaAdsma, H. W., Swan, A. A., Ponzoni, R. W. (1996): Resistance to nematode parasites in Merino sheep: sources of genetic variation. Aust. J. Agric. Res., 47: $895-$ 915

Else, K. J., FinkELMAN, F. D. (1998): Intestinal nematode parasites, cytokines and effector mechanisms. Int. J. Parasitol., 28: 1145 - 1158

Escayg, A. P., Hickford, J. G. H., Motgomery, G. W., DodDs, K. G., Bullock, D. W. (1996): Polymorphism at the ovine major histocompatibility complex class II loci. Anim. Genet., 27: $305-312$

Fabb, S. A., Maddox, J. F., Gogolin-Ewens, K. J., BAKER, L., WU, M. J., BRANDOD, M. R. (1993): Isolation, characterization and evolution of ovine major histocomatibility complex class II DRA and DQA genes. Anim. Genet., 24: 249 - 255

GAMBLE, H. R., ZAJAC, A. M. (1992): Resistance of St. Croix lambs to Haemonchus contortus in experimentally and naturally acquired infections. Vet. Parasitol., 41: $211-225$

Gause, W. C., Urban, Jr., Stadecker, M. J. (2003): The immune response to parasitic helminthes: insights from murine models. Trends Immunol., 24: 269 - 277

Gruszczyńska, J., Brokowska, K., Charon, K. M., ŚWIDEREK, W. P. (2005): Restriction fragment length polymorphism of exon 2 Ovar-DRB1 gene in Polish Heath Sheep and Polish Lowland Sheep. J. Appl. Genet., 46: 311 $-314$

Gruszczyńska, J., Charon, K. M., ŚwidereK, W., SAWERA, M. (2002): Microsatellite polymorphism in locus OMHC1 (MHC Class I) in Polish Heath Sheep and Polish Lowland Sheep (Żelazna variety). J. Appl. Genet., 43: 217 $-222$
Hediger, R., Ansari, H. A., Stranzinger, G. F. (1991): Chromosome banding and gene localizations support extensive conservation of chromosome structure between cattle and sheep. Cytogenet. Cell Genet., 57: 127 - 134

Henderson, N. G., Stear, M. J. (2006): Eosinophil and IgA responses in sheep infected with Teladorsagia circumcincta. Vet. Immunol. Immunopathol., 112: 62 - 66

Kaufman, J., Salomonsen, J., FlajniK, M. (1994): Evolutionary conservation of MHC class I and class II molecules - different yet the same. Semin. Immunol., 6: $411-424$

Keane, O. M., Dodds, K. G., Crawford, A. M., MCEWAN, J. C. (2007): Transcripstional profiling of Ovis aries identifies Ovar-DQA1 allele frequency differences between nematode resistant and susceptible selection lines. Press. Physiol. Genomics., 30: 253 - 261

Maizels, R. M., Bundy, D. A. P., Selkirk, M. E., SMith, D. F., ANDERSON, R. M. (1993). Immunological modulation and evasion by helminth parasites in human populations. Nature, 365: $797-805$

McEwan, J. C., Mason, P., Baker, R. L., Clarke, J. N., HICKEY, S. M., TURNER, K. (1992): Effect of selection for productive traits on internal parasite resistance in sheep. Proc. N. Z. Soc. Anim. Prod., 52: 53 - 56

Meeusen, E. N. T., Balic, A., Bowles, V. (2005): Cells, cytokines and other molecules associated with rejection of gastrointestinal nematode parasites. Vet. Immunol. Immunopathol., 108: $121-125$

Morris, C. A., Vlassoff, A., Bissett, S. A., Baker, R. L., West, C. J., Hurford, A. P. (1997): Responses of Romney sheep to selection for resistance or susceptibility of nematode infection. Anim. Sci., 64: 319 - 329

MoskwA, B. (1999a): The imune response against gastrointestinal nematodes in naturally infected Polish Wrzosówka sheep. I. The serum IgG response to Haemonchus contortus in ewes over three grazing seasons. Acta Parasitol., 44: 266 - 273

MoskwA, B. (1999b): The immune response against gastrointestinal nematodes in naturally infected Polish Wrzosówka sheep. II. The serum IgG response to nematode somatic antigens in young ewes over three grazing seasons. Acta Parasitol., 44: $274-280$

Moskwa, B., Doligalska, M., CABAJ, W. (1998): The repeatability of haematological and parasitological parameters in Polish Wrzosówka hoggets naturally infected with Trichostrongylid nematodes. Acta Parasitol., 43: $148-153$

Mugambi, J., Audho, J., BAKER, R. (2005): Evaluation of the phenotypic performance of a Red Maasai and Dorper double backcross resource population: natural pasture challenge with gastro-intestinal nematode parasites. Vet. Parasitol., 127: 263 - 275

Nowosad, B., Skalska, M., Molenda, K., Węglarzy, K., KORNAŚ, S. (2005). A comparative study of gastrointestinal nematode infections in different breeds of sheep. Part I - Ewes (only in Polish). Roczniki Naukowe Zootechniki, Supplement, 22: 295 - 298

Nowosad, B., Skalska, M., Molenda, K., Węglarzy, 
K., KoRnAŚ, S. (2005b). A comparative study of gastrointestinal nematode infections in different breeds of sheep. Part II - Lambs (only in Polish). Roczniki Naukowe Zootechniki, Supplement, 22: 295 - 298

Pernthaner, A., Shaw, R. J., McNeill, M. M., MORRISON, L., HEIN, W. R. (2005): Total and nematodespecific IgE responses in intestinal lymph of genetically resistant and susceptible sheep during infection with Trichostrongylus colubriformis. Vet. Immunol. Immunopathol., 104: $69-80$

Schwaiger, F. W., Gostomski, D., Stear, M. J., Duncan, J. L., MCKellar, Q. A., Epplen, J. T., BUITKAMP, J. (1995): An ovine major histocompatibility complex DRB1 allele is associated with low faecal egg counts following natural, predominantly Ostertargia circumcincta infection. Int. J. Parasitol., 25: 815 - 822

SteAr, M. J., BAirden, K., Bishop, S. C., BuitKamp, J., Epplen, J. T., Gostomski, D., McKellar, Q. A., Schwaiger, F. W., Wallace, D. S. (1996): An ovine lymphocyte antigen is associated with reduced faecal egg counts in four-month-old lambs following natural, predominantly Ostertargia circumcincta infection. Int. J. Parasitol., 26: 423 - 428

Stear, M. J., Henderson, N. G., Kerr, A., McKellar, Q. A., Mitchell, S., Seeley, C., Bishop, S. C. (2002): Eosinophilia as marker of resistance to Teladorsagia circumcincta in Scottish Blackface lambs. Parasitology, 124: $553-560$

Stear, M. J., InNocent, G. T., Buitkamp, J. (2005): The evolution and maintenance of polymorphism in the major histocompatibility complex. Vet. Immunopathol., 108: 53 57

Stear, M. J., Strain, S., Bishop, S. C. (1999): Mechanisms underlying resistance to nematode infection. Int. J. Parasitol., 29: $51-56$

Strain, S. A. J., Stear, M. J. (2001): The influence of protein supplementation on the immune response to Haemonchus contortus. Parasitol. Immunol., 23: 527 - 531 VAnimisetti, H. B., Andrew, S. L., Zajac, A. M., NotTER, D. R. (2004). Inheritance of fecal egg count and packed cell volume and their relationship with production traits in sheep infected with Haemonchus. J. Anim. Sci., 82: $1602-1611$

WAtson, T. G., BAKer, R. L., HARvey, T. G. (1986): Genetic variation in resistance or tolerance to internal nematode parasites in strains of sheep at Rotomahana. Proc. N. Z. Soc. Anim. Prod., 46: 23 - 26

Wetherall, J. D., Groth, D. M., Karlsson, L. J. E. (1991): DNA markers and parasite resistance in sheep: complement and major histocompatibility complex associations. Wool Res. Dev. Corp., $109-114$ 